\title{
Powieść historyczna pod czujnym okiem cenzora - analiza tekstów
}

\section{Nazo poeta - Bocheński powieściopisarz Literacki opis roli artysty w późnym komunizmie}

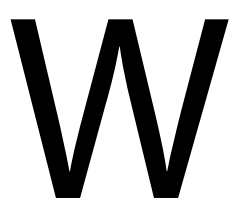

1981 roku węgierski dysydent Miklós Haraszti publikuje esej o politycznej regule, którą uznaje za esencję późnego komunizmu - stosowaniu cenzury. W eseju pojawia się wiele inspirujących intuicji, które wypływają z fundamentalnego dla tego tekstu założenia: komunizm sowiecki odniósł dziejowe zwycięstwo, już nie jest zmuszony do utrzymywania cenzury prewencyjnej w Europie Środkowo-Wschodniej, ponieważ jej obywatele, wychowani w tym systemie od niemal jednego pokolenia, poddają się jej spontanicznie. Dotyczy to zarówno prasy codziennej, jak i sztuki, i jeśli patrzeć w przyszłość pesymistycznie, wydaje się, że nic już nie może tego zmienić. Haraszti zadaje sobie pytanie, w jaki sposób scentralizowana władza wdrożyła i utrzymuje ten, działający na jej korzyść, stan rzeczy. Identyfikuje podstawowe dla niego mechanizmy: skłonność sztuki (powtarzająca się w biegu historii) do przyjmowania różnych form bałwochwalstwa, sposób selekcji stosowany przez akademie sztuk pięknych mający na celu promowanie raczej studentów lojalnych niż utalentowanych, pozorna szczodrość dotacji sowieckich, ale przede wszystkim monopolistyczna organizacja wymiany dóbr symbolicznych, która gwarantuje akumulację kapitału ekonomicznego i społecznego tylko tym, którzy postępują zgodnie 
z jej niepisanymi zasadami. Według Harasztiego w wyniku działania tych mechanizmów cenzura nie musi już występować $w$ formie prewencyjnej lub represyjnej (lub robi to bardzo rzadko). Staje się niewidoczna i może w końcu spocząć na laurach, roszcząc sobie odtąd prawo do nieistnienia.

W refleksji Harasztiego koncepcją najbardziej interesującą jest opis sytuacji krańcowej, w której cenzurze udaje się stworzyć fikcję, że mamy do czynienia z przestrzenią wolności słowa. Przy czym wolność ta jest pełniejsza niż na Zachodzie ze względu na uwolnienie się artystów od zależności ekonomicznej, która zniewala artystów w kapitalizmie. W rzeczywistości cenzura w systemie komunistycznym wspierana jest przez system dystrybucji dóbr nagradzający przestrzeganie kodeksu ideologicznego. Dlatego też osiągnęła taki poziom sprawności, że przymus stał się niepotrzebny. Aparat cenzury, który dojrzewał w systemie sowieckim, mógł się więc pozbyć uciążliwego represyjnego arsenału. Teraz preferuje niejawne metody uwodzenia i tworzenia złudzeń. Dzięki temu może utrzymywać fikcję wolności artystycznej, w której funkcjonują artyści podchodzący do tego cynicznie lub ze skrywaną niechęcią. Haraszti podkreśla niebezpieczeństwo, które tkwi w zbyt długim utrzymywaniu tego intencjonalnego oszustwa i konieczność uwolnienia się od ukrytych nakazów rządzących ekspresją artystyczną w komunizmie. Wzywa także do denuncjacji cenzury uwewnętrznionej, w pełni sprawnej i rzeczywistej.

Historycy literatury, np. Aleksander Pawlicki (2001), Przemysław Czapliński i Piotr Śliwiński (1999) lub Marta Fik (1989), komentują obficie zjawisko cenzury niewidzialnej i zgodnie uważają, że wpłynęła ona w dużym stopniu na polską powieść lat 70., przynajmniej do czasu utworzenia pierwszych wydawnictw drugiego obiegu, takich jak „NOWa”, ,"Krąg” czy „Przedświt" około roku 1976 i późniejszego pojawienia się ograniczonego obiegu tekstów nieocenzurowanych.

Jest to obszerny dorobek literacki i badanie sposobów jego kształtowania się pod wpływem niewidzialnej cenzury przekracza zakres tego artykułu. Przedmiotem tego tekstu jest analiza powieści autorstwa Jacka Bocheńskiego Nazo poeta, wydanej w roku 1969. W książce tej paradoks cenzury, która markuje swoje nieistnienie, pokazany jest z niespotykaną mocą. Tekst ten jest pasjonujący dlatego, że czyniąc z niewidzialnej cenzury jeden z głównych tematów powieści, jest jednocześnie przykładem dzieła literackiego, w którym widoczne są mechanizmy unikania i ukrywania znaczeń, które wynikają z istnienia cenzury. Tym samym jest to wyjątkowa refleksja nad zjawiskiem cenzury niewidzialnej zarówno pod względem treści, jak i formy. 
Artykuł ten ma na celu wydobycie na jaw tych mechanizmów podwójnego dyskursu, jednocześnie oskarżającego cenzurę i dostosowującego się do jej sztywnych norm. Odtworzony zostaje tekst intencjonalnie ukryty przez Bocheńskiego.

\section{Mechanizmy podwójnego dyskursu}

Nazo poeta to książka na kształt wykładu wygłaszanego przez pasjonata historii starożytnej (którym mógłby być sam Bocheński, będący narratorem w ramach własnej fikcji). Konferansjer przedstawia publiczności zagadkę procesu Owidiusza opisanego w kronice sądowej z czasu rządów tyrana Augusta. W kronikach tej epoki znajdujemy rzeczywiście wzmianki o skazaniu Owidiusza, najwybitniejszego poety rzymskiego, na wygnanie do Tomi (obecnie rumuńska Konstanca) na kresach imperium. W kronikach brak jednak informacji na temat charakteru jego przestępstwa. Sam poeta w swojej twórczości odmawia ujawnienia faktów mogących pomóc zrozumieć istotę tego, co sam nazywa swoim błędem. Wykładowca prezentuje słuchaczom wszystkie prawdopodobne hipotezy i ocenia je za pomocą dostępnej wiedzy historycznej. Mimo że opowieść zamyka się w solidnie udokumentowanych ramach historycznych, narrator skupia się przede wszystkim na odtworzeniu epizodów z życia Owidiusza i Augusta, które są raczej spekulacyjnymi rekonstrukcjami literackimi.

Opowieść narratora jest niejednoznaczna. Ma ona na celu ujawnienie źródła „błędu” Owidiusza, o którym nie wiemy prawie nic, i kończy się porażką weryfikacji przywoływanych hipotez, pozostawiając czytelnika z poczuciem niepewności i potrzebą samodzielnego wyboru hipotezy najbardziej prawdopodobnej. Najbardziej symptomatycznym elementem tego śledztwa jest widmowy charakter przestępstwa. Wina poety pojawia się wielokrotnie na kartach powieści, nie potwierdzają jej jednak żadne konkretne informacje, które mogłyby mocą kolejnych szczegółów osadzić ją w rzeczywistości, dać namacalne dowody tego zdarzenia. To stałe rozmycie potęguje atmosferę ogólnego zagrożenia, wynikającego ze stosowania zasady domniemania winy, z odwróconego porządku państwa prawa. Domniemanie niewinności (praesumptio boni viri) staje się domniemaniem winy. „Dajcie mi człowieka, a paragraf się znajdzie" miał powiedzieć Andriej Wyszynski, prokurator ery stalinowskiej w Związku Radzieckim. Bocheński przywołuje tę atmosferę, gdy mówi:

„Wina Owidiusza przesuwała się niepostrzeżenie. Notujemy w śledztwie, że wina była ruchoma. [...] Podobnie do nas w śledztwie, Owidiusz musiał postępować krok w krok za winą i rozstrzygać, którą jej lokalizację i którą postać przyjmie, ponieważ wzięcie 
winy na siebie stawało się w jego położeniu oczywistą koniecznością" (Bocheński, 1969, ss. 208-209).

Hipoteza, która pozwala najlepiej dopasowywać do siebie elementy śledztwa, wskazuje na artystyczny charakter winy Owidiusza. Jest to pierwsza hipoteza przywołana przez narratora, ta, której poświęci później najwięcej uwagi. Powraca ona regularnie, podczas gdy inne możliwości, bardziej poszlakowe (takie jak sugestia, że Owidiusz był świadkiem skandalu obyczajowego, w którym główną rolę odegrała córka Augusta, Julia Starsza, lub przeczytał fałszywkę pamfletu, który cesarz zamówił, by wyeliminować politycznego rywala), przywoływane są tylko raz, a następnie zostają zakwestionowane i odrzucone. Gdybyśmy chcieli graficznie przedstawić narrację powieści, hipoteza artystyczna byłaby wątkiem głównym, główną drogą, z której odchodzą drogi na skróty, czyli hipotezy poszlakowe. Możemy więc przypuszczać, że to w twórczości Owidiusza powinniśmy szukać źródeł jego winy i to ta hipoteza najbardziej pobudza wyobraźnię autora.

Jeśli zgodzimy się uznać, że autor postanowił wyróżnić w kompozycji swojego dzieła artystyczne źródła przewiny poety, musimy także pokazać, w jaki sposób jest ona reprezentowana w narracji. Trzeci i ostatni rozdział, poświęcony wynikom śledztwa, krąży zawile wokół tej kwestii. Artystyczna wina Owidiusza nie wydaje się być ograniczona do jednego aktu. Jest to połączenie kilku obciążających mechanizmów oskarżenia, które narrator opisuje z wielką przenikliwością.

Podczas spotkania, wymyślonego i zainscenizowanego przez konferansjera, August oskarża Owidiusza o to, że nie przyczynia się do budowania wielkości Rzymu.

„[...] co w swoim życiu zrobiłeś dla ojczyzny, jakiego dobra przysporzyłeś temu narodowi, czym i kiedy? [...] chciał powiedzieć, że przecież jest poetą, lecz w końcu nie powiedział nic, bo cios wydał mu się tak wymierzony, że odpierając go można było jedynie pogrążyć się jeszcze bardziej. Czy poeci nie są obywatelami? Ciągnął August. Czy wszyscy obywatele nie są równi wobec ojczyzny? A może poezja uwalnia obywatela rzymskiego od podstawowych obowiązków, może daje prawo do samowoli i nierządu? To ma być ta wasza wielkość? To jest nadużycie, małe, nędzne pasożyctwo samolubów" (Bocheński, 1969, s. 203).

Definiując poezję Owidiusza jako pasożytniczą, August wprowadza wyraźne rozróżnienie między sztuką przydatną a sztuką zbędną. Kryterium, które pozwala na przypisanie dzieła do jednej lub drugiej kategorii, to skuteczność jego zaangażowania dla wspólnej sprawy (Rzymu), wymagająca wysiłku wszystkich (obywateli). Sztuka jest tu postrzegana w kategoriach podporządkowania projektowi politycznemu (wielkości Rzymu). Haraszti nie 
sugerował nic innego, mówiąc, że "działalność artystyczna w społeczeństwach komunistycznych jest powiększona o relację, która ją wiąże z całością [projektu komunistycznego], a artysta jest wyposażony w narzędzie, dzięki któremu będzie mógł artystycznie kształcić to 'wielkie ciało'" (Haraszti, 1983, s. 63). Konsekwencją rozróżnienia, którym operuje August pomiędzy sztuką przydatną a sztuką zbędną - jest redukcja działalności artystycznej do roli środka i odmówienie jej prawa do bycia celem samym w sobie.

Tak zdefiniowana rola artysty przypomina określenie Stalina „inżynierowie dusz ludzkich". Mieli to być inżynierowie tacy jaki inni, tyle że pracujących z materiałem o większej złożoności, którego przekształcanie musi przyczyniać się do jedynego wielkiego dzieła - budowy komunizmu. Użycie terminu "pasożyctwo" jest rozpoznawalne przez polskiego czytelnika końca lat 1960 jako zapożyczenie ze stalinowskiej propagandy, a nawet antyintelektualnej kampanii zainicjowanej przez Gomułkę po wydarzeniach marcowych 1968 roku. Ciekawe są tu spostrzeżenia Bogusława Sułkowskiego w artykule poświęconym językowi ezopowemu (1992). Przywołuje on wyniki swoich ankiet, potwierdzające zdolność polskich czytelników do politycznej przenikliwości interpretacyjnej podczas lektury. Jesteśmy świadkami tego, co Bachtin opisał jak użycie słowa za echem głosów, które można jeszcze w nim dostrzec (Bakhtin, 1929). Widzimy, że z katalogu semantycznego, który obejmuje kategorie nieuczciwego zysku, autor świadomie wybiera termin „pasożyctwo”, ponieważ pozwala mu odzyskać jego wartość konotatywną i przeprowadzić analogię między rozumieniem sztuki przez cesarza i rozumieniem sztuki przez przywódców radzieckich, stawiając dyskretny znak równoważności między tymi postaciami.

Drugi zarzut postawiony Owidiuszowi przez Augusta to niepraktykowanie cnót idealnego obywatela w życiu prywatnym. Inaczej mówiąc, chodziło o to, że poeta był osobą publiczną, lecz nie dbał o rozpowszechnienie rzymskich cnót obywatelskich. August mówi:

„[...] byłeś przykładem zepsucia, smutnym okazem wyrodnienia cnót rzymskich i ogniskiem niebezpiecznej zarazy, które muszę wyciąć, jak lekarz wycina zakażoną część organizmu, by ratować całość" (Bocheński, 1969, s. 203).

Ten zarzut uzupełniony jest kolejną symetryczną krytyką niemoralności pism Owidiusza: „A właśnie byłeś wzorem tej zgnilizny i to jest najgorsze. Byłeś wzorem, wyrocznią i nauczycielem wszystkich zgniłków moralnych. Czcili cię, studiowali, miałeś tych swoich wyznawców" (Bocheński, 1969, s. 205). 
W tej inkryminacji cesarz próbuje ustalić linię współzależności między życiem artysty i jego dzieła. Wpisuje w sekwencję przyczynową rzekomą niemoralność poety i ton jego dzieła. Odsłania więc swoją mechaniczną koncepcję twórczości literackiej, która jest niczym innym niż tekstualnym przedłużeniem biografii autora. Jest to zgodne ze skostniałą marksistowską koncepcją kultury jako jednego z elementów nadbudowy, według której każde dzieło jest odzwierciedleniem świadomości autora, która z kolei jest w zasadzie określona przez jego pochodzenie klasowe. Tak więc krytycy marksistowscy pospołu z cesarzem Augustem przekonani są o niemożności oderwania się sztuki od warunków jej produkcji. Jest to powód, dla którego biografia artysty zawsze z góry stanowiła zbiór aktów oskarżenia w procesie, który można mu było wytoczyć w każdej chwili.

Ta nieufność jest doskonale widoczna $w$ dyfamacyjnych kampaniach prowadzonych przeciw dysydenom. Władze starały się wykorzystać informacje o szczegółach ich życia prywatnego, aby rzucić cień podejrzenia na efekty ich pracy. Podobnie postępuje August.

Idea, że życie i twórczość artysty cechują podobieństwa, miała dla władzy niezaprzeczalną zaletę. Jeśli każdy tekst miał swoje źródło w biografii pisarza, to każdy tekst, w którym była mowa o przekraczaniu granic moralności, można było uznać za przyznanie się autora do winy. Wynikało z tego, że dopuszczalne były jedynie historie stawiające ich autorów poza wszelkim podejrzeniem, a więc budujące i umoralniające. Krótko mówiąc, historie, które przyczyniały się do propagowania postaw sprzyjających realizacji politycznego projektu prowadzonego przez władzę.

Co więcej, jest to niemal słowo w słowo to, co August zaleca Owidiuszowi, kiedy radzi mu uczyć się od postaci mu współczesnej - od Wergiliusza. Mówi:

„Pamiętam też, jak z pobudek obywatelskich zabrał się do poematu o rolnictwie. Napisał wtedy pochwalę ziemi i pracowitości, dzieło ważkie, pouczające. Więc on, ten wielki poeta, którego wyobraźnia lgnęła zawsze do rzeczy pięknych i szlachetnych mógł tak pisać, bo rozumiał powołanie pisarza, czuł się odpowiedzialny za skutki, tego co pisze [...]" (Bocheński, 1969, s. 205).

Odnotujmy, że jest to komplement, którym komunistyczny przywódca mógłby obdarować - powiedzmy - Jerzego Andrzejewskiego na początku lat 1950 bez żadnej zmiany w tekście! August uszczegóławia tutaj swoją koncepcję roli artysty. Wydaje się formułować w toku swojej wypowiedzi odwrót od osądu estetycznego, który następuje w społeczeństwach komunistycznych. Haraszti opisuje go tak: „Artysta zaangażowany nie tworzy sztuki. Artysta zaangażowany tworzy społeczeństwo. [...] W tej sytuacji podporząd- 
kowania, jakość dzieła sztuki nie zależy od spójności dzieła, ani od współzależności między jego elementami, ni od jego innowacyjności. Harmonia elementów zostaje zapewniona pragmatycznie przez swoją wspólną funkcję; ponieważ mają one ten sam cel, nie potrzebują być ani oryginalnymi ani indywidualnymi." (Haraszti, 1983, s. 65). Ponownie sztuka jest tylko i wyłącznie środkiem do celu, który leży poza nim i niejako nad nim, i wykazuje w sposób jednoznaczny swoje podporządkowanie. Jest więc wiele wymagań, których nie spełniał w swojej poezji Owidiusz.

Nieco dalej August prezentuje jedną z głębokich uraz, którą żywi wobec poety:

„[...] w twoich poezjach nie ma wielkości Rzymu, nie pada nawet moje imię” (Bocheński, 1969, s. 207).

Jednak fakty zaprzeczają temu zarzutowi. W poezji Owidiusza można odnaleźć kilka pochwalnych odniesień do cesarza. Dzięki tej krytyce możemy zdać sobie sprawę, jak wielki apetyt na pochlebstwa miał suweren, który uważał, że kilka konwencjonalnych pochwał nieprzekonująco demonstruje podziw. Wiersze Owidiusza są naszpikowane czczymi pochlebstwami, jednak nie na tyle nieumiarkowanymi, aby zaspokoić wilczy głód cesarza. Sam Owidiusz sugeruje hiperboliczny trop głodu, gdy stwierdza:

„[...] to Eryzychton, ginie z wycieńczenia, zje samego siebie” (Bocheński, 1969, s. 207).

Kompetentny polski czytelnik, przyzwyczajony do mowy ezopowej polskiej powieści, dostrzegł zapewne aluzję do profilu psychologicznego przywódców komunistycznych, zwłaszcza Stalina, którego kompulsywna potrzeba uznania spowodowała, że twórczość kulturalna stała się przede wszystkim przemysłem obsługującym kult jego osoby. Jest to także nawiązanie do pierwszej części trylogii rzymskiej Bocheńskiego Boski Juliusz, odczytywanej jako rozliczenie z kultem jednostki (np. Walc, 1992).

August tak kończy listę zarzutów:

„... jeszcze o powołaniu pisarza. Słowa, słowa, wszystko to są słowa, a wartość słów poznaje się po skutkach. Słowa mają skutki. Każdy, kto używa słów, chce osiągnąć jakiś skutek. [...] Tylko zdaje się, nie poeci. [...] Bo oni są czymś wyższym, oni uważają, że im wolno, ich żadne skutki nie obchodzą. Ale te skutki są! Bywają złe, zgubne i zbrodnicze. A na to nie pozwolę" (Bocheński, 1969, s. 208).

August kończy tam, gdzie zaczął: słowa nie mogą już udawać, że są jedynym horyzontem! Obwinia Owidiusza za niezrozumienie tego, co Haraszti wyraża w sposób następujący: 
„najbardziej trwałym i jednocześnie najbardziej instynktownym spośród tych [nowych] zasad estetycznych wydaje się być zakaz samoreferencyjności" (Bocheński, s. 158). Jak zauważa Antonina Kłoskowska w artykule poświęconym pojęciu wolności symbolicznej (1992), człowiek władzy, jakim jest cesarz, musi w pewnym stopniu traktować dyskurs w kategoriach, które mogą być opisane - według teorii Austina (1962) - jako perlokucyjne akty mowy.

\section{Przykręcanie śrub rzeczywistości}

Dyskurs artystyczny jest dla Augusta nie tyle skupiskiem znaczeń, co aktem intencjonalności. Dyskurs ten stara się stworzyć realne konsekwencje za pomocą swej mocy perswazyjnej. Jest to klucz angielski (inaczej nastawny) w dłoni inżyniera, którym przykręca śruby rzeczywistości. Ale Owidiusz odmawia włożenia niebieskiego fartucha i dołączenia do grona budowniczych Rzymu. August zarzuca mu ucieczkę od odpowiedzialności i odmawia mu prawa do specjalnego statusu. Owidiusz jest po pierwsze obywatelem Rzymu, a dopiero później poetą.

August miał tutaj taką samą jak później władze komunistyczne wizję wzorcowego artysty, którą Haraszti określa tak: „artysta zaangażowany jest znakomitym planistą społecznym, w obu znaczeniach tego słowa: określa cele, i jest ich wykonawcą. Jest nie tylko inspiratorem, ale także organizatorem publiczności" (Bocheński, 1969, s. 67). Cesarz uważał, że winą poety było zignorowanie faktu, iż pod jego rządami była to jedyna prawowita misja, ponieważ jako jedyna wpisywała się we wspólny wysiłek budowania Rzymu.

Przeglądając tę litanię zarzutów postawionych Owidiuszowi, widzimy, że jego wina jako artysty polega nie tyle na popełnieniu zakazanego czynu (niemoralności jego pism), ile na braku działania (na odmowie tworzenia budujących poematów, niewystarczającym uznaniu wielkości cesarza, nieokazywaniu podporządkowania się Rzymowi). Poczucie winy artysty w komunizmie, przedstawione alegorycznie jako wina Owidiusza, jest więc winą wirtualną, tymczasowo zawieszoną i w jakimś stopniu nie do udowodnienia. Artysta w komunizmie jest stale oceniany za to, czego nie zrobił we wspólnym wysiłku, dla wspólnego dobra. Jest odpowiedzialny za książkę, której jeszcze nie napisał. Wracamy tutaj do widmowego charakter winy, która, jak widać, nie polega na złamaniu tabu, lecz na odmowie przestrzegania systemu zobowiązań. Jednak w czasach, gdy system komunistyczny utracił legitymizację i niechętnie manifestował swój autorytaryzm, trudne stało się oskarżanie osób cieszących się autorytetem z powodu braku rewolucyjnego zapału. Dlatego ten grzech pierworodny 
artysty miał być niedopowiedziany i przebrany w szaty tysiąca innych przewinień. Jest jednak faktem, że nadal przenikał każdą recenzję, każdą publikację i każdy odczyt.

\section{Obsesyjny konformizm}

Owidiusz zauważył również, że cesarz pewnie nie tracił swojego cennego czasu na odprężające i lekkie lektury, takie jak jego wiersze, i jest wysoce prawdopodobne, że swój sąd oparł na cudzych opiniach. Dodaje jednak:

„[...] opinie przedstawione Augustowi nie mogą być obiektywne, bo nad samym ich poczęciem ciąży chwalebny skądinąd szacunek dla nastrojów Augusta i opinie rodzą się już nastawione w pewnym kierunku, uchodzącym za właściwy. Tylko August widzi w nim rozpoznanie prawdy, kiedy w rzeczywistości są one raczej rozpoznaniem drgnień duszy Augusta. August jednak na podstawie tych opinii podejmuje decyzje, których słuszności nie może z kolei sprawdzić, ponieważ o skutkach swych decyzji dostaje znów opinie oparte nie na faktach, lecz na poszanowaniu jego nastrojów. Tu zamyka się błędne koło. [...] Decyduje o fikcjach, wymyślanych dla jego satysfakcji przez opiniodawców" (Bocheński, 1969, s. 206).

Owidiusz wykazuje tu ruchomy i niejasny charakteru obowiązków, którym podporządkować ma się artysta i to, w jaki sposób były one rozumiane przez cenzorów. Cenzorska interpretacja nie mogła być dokładna, ponieważ była ona produktem błędnego koła systemu administracyjnego, który w swym obsesyjnym konformizmie ideologicznym często wykazywał nadmierną gorliwość. Artysta był więc nieustannie podejrzewany o niezgodność z wymogami. Z ich definiowaniem mieli zresztą trudności sami cenzorzy.

System ten ma wiele punktów zbieżnych z opisanymi przez Darntona (2014) mechanizmami powstawania opinii cenzury prewencyjnej w latach 80. w Niemczech Wschodnich. Na podstawie badań archiwalnych i wywiadów z byłymi urzędnikami cenzury, udało mu się prześledzić drogę przekazywania opinii cenzorów przedstawicielom kultury, aby mogli oni podjąć decyzję bądź co do nakładu danego dzieła literackiego, bądź zakazu jego publikacji. Analiza Darntona podkreśla zasadnicze znaczenie opinii cenzorów, których recenzje były jedynymi dokumentami opisującymi rzeczywistość, z którą politycy nie mieli czasu się zapoznawać. W analogiczny sposób pokazuje on błędne koło opisu zdeformowanego przez konformizm, wynikający z instytucjonalnej pozycji cenzorów: starali się oni przewidzieć oczekiwania przełożonych w sytuacji, w której władza rzadko formułowała swoje cele, a jeśli już to robiła, to w sposób bardzo niejednoznaczny. 
Poeta nie daje jednak silnego odporu tym oskarżeniom. Co najwyżej mamrocze pod nosem kilka słów sprzeciwu. Ta względna bierność zaskakuje, ponieważ wydaje się przyznawać retoryczne zwycięstwo cesarzowi. Narrator uzasadnia to stwierdzeniem, że poeta uznaje swoją winę, aczkolwiek nie jest ona jednoznaczna z zarzutem Augusta.

Kończąc swoją książkę, Bocheński bierze poetę w obronę:

„Ale właśnie dlatego, że widział wielkość, że uwierzył w boską konstytucję augustiańskiego świata, [...] właśnie dlatego chciał pisać tak prawdziwie, jak się pisze wobec Boga. [...] Pisał, jak mógł i musiał, pisał właśnie prawdę, lecz ta najuczciwsza prawda okazywała się niepobożna" (Bocheński, 1969, s. 262).

Następuje tu odwrócenie hierarchii lojalności. Prawdziwy artysta to ten, który wciąż w mniejszym stopniu podporządkowuje się władzy niż zasadom sztuki. Nie dlatego, że bierze udział w akcie sprzeciwu wobec władzy. To autentyczna niezdolność Owidiusza do pisania niezgodnie z zasadami poetyckimi. Jak pisze Bocheński:

„[...] posłuchał jakiegoś dyktatu, narzuconego mu w toku pisania przez niezależne prawa poezji, uległ jej samorządowi, [...] nie rozstrzygnął kwestii, czy prawda jest godziwa, skoro dostrzegł, że nadaje się do opisu" (Bocheński, 1969, s. 263).

Kończy, porównując swojego protagonistę do bohatera pewnej bajki, którą cytował kilka stron wcześniej:

„Do tyrana Agrygentu, Falarysa, zgłosił się kiedyś pewien nikczemnik. Dokonałem wynalazku, powiada. Zrobiłem wielką figurę spiżową w kształcie byka. Ta figura może jednak ryczeć. Jest mianowicie pusta w środku, wystarczy ją nadziać pierwszym lepszym skazańcem i rozpalić ogień pod spiżowym brzuchem, a po chwili wyda z siebie głos. Dziwny zaiste wynalazek, rzekł tyran Falarys, wypróbujemy go niezwłocznie na tobie. Przypowieść tę otrzymał od poety nieznany z imienia szubrawiec" (Bocheński, 1969, s. 242).

\section{Wynalazek Owidiusza}

Łatwym do popełnienia błędem interpretacyjnym byłoby utożsamianie postaci Agrygenta i Augusta, czyli odczytanie tej paraboli jako kontynuacji sporu pomiędzy poetą i cesarzem. Jednak Bocheński sugeruje inne znaczenie tej bajki, kiedy powraca do niej w końcowych stronach swojej powieści: „Wynalazek obracał się przeciwko swemu twórcy. I słusznie! 
Bo dokonanie tego wynalazku było rzeczywistą winą Owidiusza, do której się przyznawał, robiąc najgłębszy rachunek sumienia" (Bocheński, 1969, s. 264).

Sugeruje on więc, że ta parabola ma sens tylko wtedy, gdy przyjmiemy, że Agrygent jest alegorycznym przedstawieniem jedynego mistrza, którego uznaje Owidiusz, to jest poezji. Powinniśmy więc rozumieć, że poeta (Falarys) w służbie sztuki (Agrygent) opracował nowy, fascynujący sposób wyrazu rzeczywistości (spiżowego Byka), jednak technika ta wymaga od niego poświęcenia i działa tylko wtedy, kiedy to poświęcenie jest bezwarunkowe. Bocheński postuluje w gruncie rzeczy istnienie powołania artysty, które byłoby esencją, która poprzedza jego egzystencję i od której nie da się uciec. Esencja byłaby swoistego rodzaju klątwą, która eliminuje pojęcie wyboru. Narrator daje temu wyraz w końcowym zdaniu przywołanego ustępu: „A już pewnie nie Cezar, lecz sama poezja skazuje poetów na winę [...]" (Bocheński, 1969, s. 264).

Zaproponowana przez Owidiusza kontrdefinicja artysty jest interesująca z dwóch powodów. Po pierwsze, czyni z niego istotę w jakiś sposób odporną na naciski władzy. Nie dlatego, że nie odczuwa on ich skutków lub dlatego, że ma odwagę im się przeciwstawić, ale dlatego, że jest w swej esencji podporządkowany tyranowi jeszcze bardziej despotycznemu, czyli swojej sztuce. Ta definicja brzmi jak wezwanie do zachowania specyficznego statusu artysty, koncentrując się na przywróceniu mu autonomii. I wreszcie, ta kontrdefinicja autorstwa Owidiusza rodzi pytanie o stosunek do niej samego Bocheńskiego. Czy dotknęła go ta sama klątwa co Owidiusza? Czy jest tak samo niepodzielnie oddany sztuce? Czy jest w stanie ignorować nakazy władzy?

Co interesujące, aby wydobyć warstwę eseistyczną, typową dla powieści hybrydowej (Grochowski, 2000, który pisze w ten sposób o Boskim Juliuszu), i zrekonstruować ją w całej jej wyrazistości, należało rozszyfrować cały szereg połączeń alegorycznych i ułożyć je w logiczną serię, która w porównaniu z oryginałem jest bardziej linearna i skondensowana. Nawet jeśli polski czytelnik miał okazję oswoić się z tego typu lekturą przeczytawszy powieści historyczne z końca lat 50., takie jak Ciemności kryja ziemię (1957) Jerzego Andrzejewskiego lub wcześniejszą powieść Jacka Bocheńskiego Boski Juliusz (1961), nie ulega wątpliwości, że autor wykazał się tutaj pewną rozwagą. Co nie oznacza, że Bocheński nie stara się wzbudzić żadnych wątpliwości, nakierowując czytelnika na przedstawiony w toku analizy sposób lektury. Widać to wyraźnie na początku książki, gdy komentuje kryteria, które zdeterminowały wybór gatunku powieści i sugeruje najodpowiedniejszy sposób lektury swojego tekstu: 
„Ależ oczywiście, mam na uwadze styl czasu, a styl obowiązuje jak prawo przyrody. [...] W przyszłości staram się wykazać, że styl jest nam dany, że go nie tworzymy, ani nawet nie wybieramy" (Bocheński, 1969, s. 7).

A w innym miejscu:

„Jeszcze wyjaśnienie w sprawie czasu. Czas, podobnie jak styl, jest nam dany. Postaram się wykazać to kiedy indziej, tu pokrótce nadmienię, że nikt z nas osobiście nie przebywa w przeszłości, czyli w tym, co było. Lecz uświadomić sobie przeszłość, w której nas nie ma, można jedynie teraz, gdy właśnie jesteśmy, a wyrazić ją można jedynie takim stylem i takimi słowami, jakie w teraźniejszości są nam dane" (Bocheński, 1969, s. 9).

Pomimo to postanawia jednak utrudnić zrozumienie swego tekstu. Możemy sobie oczywiście wyobrazić, że decyzja o umieszczeniu akcji w antycznych dekoracjach może być zrozumiana jako wyraz woli artysty, by dokonać transpozycji jednej realności w inną i próbę uwiedzenia czytelnika poprzez historyczną scenerię. Jednak pozostaje faktem, że część tekstu powieści poświęcona cenzurze nurza się w aurze tajemniczości, która może wywołać u czytelnika pewną konfuzję. Argumentacja narratora traci tu jasność i moc przekonywania. Wynika to prawdopodobnie z trudności, którą Bocheński pozwala wyjaśnić Owidiuszowi:

„Można także zrozumieć, jak trudne było zadanie autora. Musiał mieć wciąż na oku cel praktyczny: wywołać tę rewizję, w której widział jedyną możliwość ratunku. Nic nie zepsuć! Stworzyć należyte argumenty przemawiające za zwolnieniem. Uniknąć tematów zabronionych. Nie skompromitować się przed nikim: ani przed Augustem, ani przed czytelnikami. A pisać do wszystkich jednocześnie" (Bocheński, 1969, s. 196).

Aby osiągnąć cel praktyczny, w tym wypadku zapewnić sobie publikację powieści i odnieść sukces czytelniczy, Bocheński musiał wziąć pod uwagę dwa rodzaje czytelników: władzę i publiczność. Nie może ryzykować rozczarowania jednego z nich. To praktyczne podejście do pisarstwa rzuca jeszcze inne światło na przytoczoną wcześniej definicję podszytą duchem romantyzmu - artysty z esencji, bezwarunkowo podporządkowanego sztuce. Jeśli Bochenski pragnie być jej użytecznym i pragmatycznym poddanym, nie może całkowicie odrzucić wymagań władzy. Musi podporządkować się niezliczonym wymaganiom wykraczającym poza sferę artystyczną. To wyjaśnia, dlaczego wolał posłużyć się wątkiem alegorycznym przeplatającym się w całym tekście, niż skoncentrować tematykę stosunku do cenzury w jednym z rozdziałów. Przekaz musiał być ukryty i rozproszony, aby w ogóle mógł dotrzeć do adresata. Sens migocze zaledwie w różnych fragmentach powieści, jeśli 
posłużyć się sformułowaniem Anny Ładan, którego używa ona do rozważań nad postmodernistycznym statusem tej powieści (2012).

Innymi słowy, Bocheński sztucznie komplikuje rozważania narratora o mechanizmach cenzury, aby utrudnić dostęp do książki i ograniczyć zakres jej dystrybucji, a tym samym zapewnić władzy komunistycznej wystarczające gwarancje, że tekst ten nie ma szkodliwego wpływu na postrzeganie jej prawomocności przez ogół społeczeństwa. To jest cena, którą musiał zapłacić za jego rozpowszechnianie.

Ta niejednoznaczność odgrywa w dziele Bocheńskiego dwie podstawowe role. Jak widzieliśmy, to ona wywraca do góry nogami zasadę domniemania niewinności, przekształcając ją w domniemanie winy, i jest główną zasadą funkcjonowania cenzury niewidzialnej. Niejednoznaczność ta wynika również z rozumowania, które nie może być w pełni rozwinięte, ponieważ stawia w stan oskarżenia pierwszego czytelnika - cenzora. Artystyczna wina Owidiusza nie może więc być nigdy całkowicie ujawniona publiczności, ponieważ uderza bardziej w osobę sędziego niż w samego oskarżonego. Innymi słowy, literacka szczerość jest błędem, jest zakazana implicite, i władze nie mają ochoty na wyciąganie tych zakazów na światło dzienne. Dlatego też wolą, żeby przestępstwo, którego dopuścił się Owidiusz, pozostało nieuchwytną tajemnicą. Właśnie to proponuje im Bocheński.

Kończąc tę analizę, chciałbym podkreślić moc tego zabiegu kompozycyjnego. Organizując tekst wokół niejednoznaczności, Bocheński w tym samym geście literackim gwarantuje władzy swoją prawomyślność, tematyzując - nawet jeśli w niedookreślonej i subtelnej formie - w swojej powieści sposób funkcjonowania niewidzialnej cenzury.

\section{Bibliografia}

Andrzejewski, J. (1957). Ciemności kryją ziemię. Warszawa: Spółdzielnia Wydawnicza "Czytelnik". Austin, J. L. (1962). How to do things with words. Oxford: Oxford University Press.

Bakhtin, M. (1929). Problemy tvorchestva Dostoevskogo. Leningrad: Priboĭ.

Bocheński, J. (1961). Boski Juliusz. Warszawa: Spółdzielnia Wydawnicza "Czytelnik".

Bocheński, J. (1969). Nazo poeta. Warszawa: Spółdzielnia Wydawnicza "Czytelnik”.

Czapliński, P. \& Śliwiński, P. (1999). Literatura polska 1976-1998. Kraków: Wydawnictwo Literackie.

Darnton, R. (2014). Censors at work: How states shaped literature. New York: W. W. Norton.

Fik, M. (1989). Kultura polska po Jałcie. Warszawa: Polonia. 
Grochowski, G. (2000). Tekstowe hybrydy: Literackość i jej pogranicza. Wrocław: Wydawnictwo Uniwersytetu Wrocławskiego.

Haraszti, M. (1983). L'artiste d'Etat : de la censure en pays socialiste. Paris: Fayard.

Kłoskowska, A. (1992). Kontrola myśli i wolność symboliczna. W J. Kostecki \& A. Brodzka (Red.), Piśmiennictwo - systemy kontroli - obiegi alternatywne (T. 1, ss. 9-19). Warszawa: Biblioteka Narodowa, Instytut Książki i Czytelnictwa.

Ładan, A. (2012). Historia, narracja, kreacja - „Boski Juliusz” i „Nazo poeta” Jacka Bocheńskiego. Pamiętnik Literacki, 103(3), 127-141.

Pawlicki, A. (2001). Kompletna szarość, cenzura w latach 1965-1972: Instytucja i ludzie. Warszawa: Wydawnictwo Trio.

Sułkowski, B. (1992). „Ten przeklęty język ezopowy”: O społecznych mechanizmach komunikacji cenzurowanej. W J. Kostecki \& A. Brodzka (Red.), Piśmiennictwo - systemy kontroli - obiegi alternatywne (T. 2, ss. 266-284). Warszawa: Biblioteka Narodowa, Instytut Książki i Czytelnictwa.

Walc, J. (1992). Vae divis. W J. Walc, Wielka choroba. Warszawa: Wydawnictwa Szkolne i Pedagogiczne.

\section{The historic novel under the vigilance of the censor - analysis of texts}

This article focuses on the relation that Jacek Bochenski's historical novel entitled The poet Naso published in 1969 presents towards the concept of censorship. In the article the author aims at proving that the understanding of censorship by Bochenski is similar to the observations of the Hungarian essayist Mikos Haraszti. Tracking the allegoric references scattered through the novel, the author of the article reconstructs Bochenski's reflection about this internalized censorship and checks its convergence with Haraszti's remarks. From this exercise emerges a definition of the role of the artist that seems to be inherited from the romantic period: an artist as a person that subordinates himself unconditionally to art, and not to the temporal power. The author of the article then interrogates the respect which Bochenski has been showing to his definition in his literary work. It appears that the writer has been prone to make bigger concessions in order to soften the reception of his book by the censors than he advises his writing colleagues. However, the literary strategies deployed by Bochenski operate on two levels: creating an overall ambiguity about the guilt of its main protagonist, they tend to soften its reception by the censorship; while at the same time, rendering this overall atmosphere of ambiguity, they give a literary form to the spectral character of the guilt of the artist, who - as in Ovidius' case - is permanently accountable for what he has not yet done in the building of communism.

\section{Keywords:}

censorship; Bocheński; Haraszti; presumption of guilt; literary strategies; allegory; historical novel; Aesopian language; role of the artist; communism; the seventies; Poland 


\section{Powieść historyczna pod czujnym okiem cenzora - analiza tekstów}

Artykuł poświęcony jest powieści historycznej Jacka Bocheńskiego pt. Nazo poeta z roku 1969 i jego rozumieniu pojęcia cenzury uwewnętrznionej. Autor artkułu udowadnia, że ujęcie problemu cenzury przez Bocheńskiego jest zbliżone do konstatacji węgierskiego eseisty Miklósa Harasztiego. Tropiąc alegoryczne odniesienia do cenzury rozproszone $w$ tej powieści, autor artykułu odtwarza refleksję Bocheńskiego i sprawdza jej zbieżność z uwagami Harasztiego. $Z$ rekonstrukcji wyłania się, zapożyczona z okresu romantyzmu, definicja artysty jako osoby bezwarunkowo podporządkowanej sztuce, a nie władzy. Autor artykułu testuje czy Bocheński pozostaje wierny tej definicji we własnej twórczości i uwypukla skłonność pisarza do ustępstw mających na celu złagodzenie odbioru jego dzieła przez cenzurę. Są to ustępstwa większe od tych, które zdaje się zalecać swoim kolegom po fachu. Strategie literackie, które stosuje Bocheński, działają jednak na dwóch płaszczyznach. Tworząc niejednoznaczność winy głównego bohatera powieści, łagodzą jej odbiór przez cenzurę, a jednocześnie - kreując tę niejednoznaczność - pozwalają na literackie przedstawienie widmowego charakteru winy artysty, który jest zawsze odpowiedzialny - tak jak Owidiusz - za to, czego jeszcze nie zrobił. W tym wypadku czego nie zrobił dla budowy komunizmu.

\section{Słowa kluczowe:}

cenzura, Bocheński; Haraszti; domniemanie winy; strategie literackie; alegoria; powieść historyczna; język ezopowy; rola artysty; komunizm; lata 70.; Polska 